\title{
Distribution of mound-building ant species (Formica spp., Hymenoptera) in Finland: preliminary results of a national survey
}

\author{
Pekka Punttila1 \& Jouni Kilpeläinen²
}

1) Finnish Environment Institute, Research Department, P.O. Box 140, Fl-00251 Helsinki, Finland
(e-mail: pekka.punttila@ymparisto.fi)
2) Finnish Forest Research Institute, Joensuu Research Unit, P.O. Box 68, Fl-80101 Joensuu,
Finland (e-mail: jouni.kilpelainen@metla.fi)

Received 13 Nov. 2007, revised version received 13 Feb. 2008, accepted 21 Mar. 2008

Punttila, P. \& Kilpeläinen, J. 2009: Distribution of mound-building ant species (Formica spp., Hymenoptera) in Finland: preliminary results of a national survey. - Ann. Zool. Fennici 46: 1-15.

In the first year's data of the 10th Finnish National Forest Inventory (2005-2008) 533 active and 178 abandoned ant mounds were found yielding 4.2 mounds ha ${ }^{-1}$. We found 11 species: Formica rufa, F. polyctena, F. aquilonia, F. lugubris, F. pratensis, F. exsecta, F. fennica, F. pressilabris, F. forsslundi, F. suecica and F. uralensis. Five species occurred throughout the country, and four were restricted to the south. We found species-specific associations with either mineral soils or mires, with forest site type and with tree-canopy openness. Low fertility decreased the occurrence of polygynous species with large worker force, and sun-exposition was favourable for species with smaller colonies presumably because only large worker force enables metabolic thermoregulation of nests. Forest fragmentation and increased amount of edge habitats favourable for colony founding have presumably increased nest density whereas drainage of mires has reduced the amount of habitat of three species since the 1950s.

\section{Introduction}

Mound building ants of the genus Formica have received a lot of attention owing to their great abundance in boreal forests and, especially in the wood ant group (F. rufa group), because of the multitude and magnitude of their ecological impacts. For instance, they affect the abundance and distribution of many forest-dwelling invertebrates (e.g. Savolainen \& Vepsäläinen 1988, Niemelä et al. 1992, Way \& Khoo 1992, Karhu \& Neuvonen 1998, Laakso \& Setälä 2000, Martikainen et al. 2000, Sipura 2002, Punttila et al.
2004) and vertebrates (e.g. Haemig 1992, 1994 , Aho et al. 1999, Jäntti et al. 2007) in all forest layers from the forest soil and floor up to the tree trunks and canopies. Further, they are important resource for both invertebrates and vertebrates (e.g. Lehtinen 1987, Gösswald 1990, Elgmork \& Kaasa 1992, Swenson et al. 1999, Päivinen et al. 2002), they play an important role in soil bioturbation (e.g. Pokarzhevskij 1981), in cycling and relocating carbon and nutrients (e.g. Lenoir et al. 2001, Kilpeläinen et al. 2007), in plant dispersal (e.g. Buckley 1982a, 1982b, Hölldobler \& Wilson 1990) and, through their involve- 
ment in mutualism with sap-sucking aphids and preying upon leaf-chewing insects, they apparently affect tree growth and plant production (e.g. Wellenstein 1980, Rosengren \& Sundström 1991, Mahdi \& Whittaker 1993, Atlegrim 2005). All these effects become reinforced and take effect on a larger spatial scale in polygynous colonies capable of forming multinest colonies. In Finland, the magnitude of these effects culminates in the top competitor F. aquilonia (e.g. Punttila et al. 1994, Punttila 1996 and references therein).

So far, however, systematic large-scale surveys of the distribution of different ant species are rare and they have concentrated mostly on the wood ant group (Burzyński 1969, Pileckis \& Vilkauskas 1973, Seifert 1991). In the 10th Finnish National Forest Inventory (NFI10, 20052008), more than 10000 sample plots $(\sim 0.05$ ha each) are surveyed for mound-building ants. Here we report preliminary results based on the first year's data. These data serve in updating the distribution maps of the species: previously only coarse-scale distribution maps have been available (e.g. Baroni Urbani \& Collingwood 1977, Collingwood 1979, Czechowski et al. 2002). Additionally, the data offer an opportunity to estimate the abundance distribution among species. This is not the first national ant survey in boreal countries, however, but the earlier surveys in Finland (NFI3, 1951-1953, see Wuorenrinne 1974, Rosengren et al. 1979, Kilpeläinen et al. 2005) and Sweden (in 2000s, see Kilpeläinen et al. 2005: 255) did not include species identification in the records of ant mounds (for the limitations of such an approach, see Kilpeläinen et al. 2005).

Here we present some general results on the occurrence of different ant species in relation to the major ecological gradients of boreal forests in Finland: forest vegetation zones (geographic area), soil type (mineral soil vs. mires), fertility (poor vs. fertile forest site types) and successional stage (open vs. closed tree canopy). Specifically, we explore whether the main patterns found in NFI3 ant mound data still hold when information about the ant species and colony vitality are taken into account. In the NFI3 data, mound occurrence decreased towards the north and was higher at fertile than at poor sites, and higher in older than in younger forest development classes (Kilpeläinen et al. 2005). Further, because our myrmecological knowledge about mires is much more limited than that about mineral soils (in NFI3, only data for mineral soils were analyzed), and because also our knowledge of the effects of mire drainage for forestry purposes is much less than of the effects of forest management (e.g. clearcutting), we compared whether the occurrences of ant species differed between drained and undrained mires.

These data allow us also to test hypotheses which predict the occurrence of wood-ant species with different social strategies in relation to stand age and disturbance regime of the forest type (see Punttila 1996). Specifically we test the hypotheses that (1) monogynous wood ant species should be more common in young successional stages before the tree canopy closure whereas polygynous wood ant species should be more common in mature, closed canopy forests, and that (2) the monogynous strategy should be favoured in pine dominated forests on poorer soils which at the 1990s (see Discussion) were presumed to be subject to more frequent disturbances by wildfire than spruce forests on more fertile soils.

\section{Material and methods}

NFI produces information on forest resources and state of forests (for details, see Korhonen et al. 2006, 2007). In the field sampling a systematic grid of clusters of sample plots is laid over the entire country. The parameters of cluster sampling vary in different parts of the country according to spatial variation of forests. In field measurements, both forest-stand and individual-tree characteristics are described. For the forest stand where a sample plot is located, more than 100 variables are observed to describe the site, growing stock, damages and need for silvicultural operations. The tree data are used for estimation of volume and increment of growing stock. The sample plot size differs slightly between southern and northern Finland (see below) because the sampling criteria for trees measured differ between southern and northern parts of the country. 
The ant nests were mapped on permanent circular sample plots of the NFI10. The radius of sample plots was $12.52 \mathrm{~m}$ in southern Finland (i.e. the two southernmost sampling areas below), and $12.45 \mathrm{~m}$ in northern Finland and thus, the plot size was a little smaller than 0.05 ha. In cases where the sample plot covered more than one stand, the ant sampling was restricted to the centre stand (the stand where the plot centre was located) resulting into reduced plot size. The size of such reduced plots was recorded in $10 \%$ classes of the whole sample plot. The majority of the ant mound plots, however, covered the whole sample plot (66\% of all plots) or at least $90 \%$ of it $(75 \%)$. All the mound density calculations are based on the exact area of the sample plots (also in the case of "reduced plot size" when the sample plot included stand edge(s)) in our analyses. All the plots are included in the frequency calculations. When calculating countrywise nest density estimates, the differing density of sampling plots in the four sampling areas (see below) was taken into account by using the forest and scrub land area represented by each of the sampling networks as a weight.

The ant mounds were inventoried on forest land (where the capability of producing volume increment is at least $1.0 \mathrm{~m}^{3} \mathrm{ha}^{-1} \mathrm{yr}^{-1}$ ) and scrub land (where the capability of producing volume increment is at least $0.1 \mathrm{~m}^{3} \mathrm{ha}^{-1} \mathrm{yr}^{-1}$ ) but not on wasteland (capability lower). Forest and scrub land cover $87 \%$ of all forestry land and $75 \%$ of total land area of Finland (Korhonen et al. 2006). The number of sample plots totaled 4150 in the first inventory year 2005. The sampling covered $40 \%$ of the permanent plots in the south, and $25 \%$ in the north. The sample plots were distributed as follows: Southern Finland (excluding Åland islands), 1448 plots, Middle Finland, 1704 plots, Northern Ostrobothnia-Kainuu (excluding Kuusamo area), 607 plots, and LaplandKuusamo (excluding northernmost Lapland), 391 plots (Fig. 1).

All ant mound nests exceeding $10 \mathrm{~cm}$ in height were included in the study when the apex of the mound situated on the sample plot (or, on the centre stand in the case of reduced ant sampling plots, see above), and the exact location in relation to the midpoint of the plot was recorded for each mound. The mounds were classified as

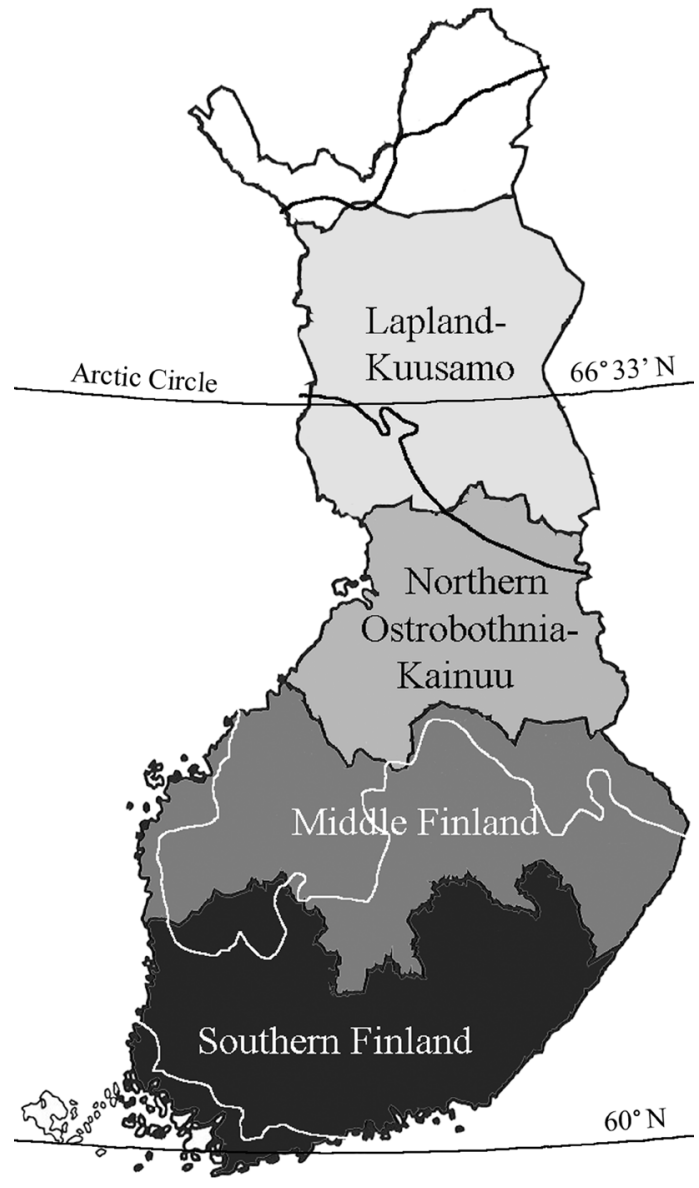

Fig. 1. The four sampling areas and their relation to the forest vegetation zones (hemi-, south-, mid- and northboreal zones (simplified from Kalela 1960, and Ahti et al. 1968).

abandoned or active, and their appearance was recorded as intact, disturbed (by man [forestry operations] or other mammals or woodpeckers [predation; the mound dimensions were still measurable]), or broken (the dimensions were not measurable). For each mound, two measurements of diameter were taken: the largest possible and the one rectangular to the largest diameter. The possible "dead" parts (decayed, over-grown by vascular plants, not under active construction by the ants) in the lower sections of the mounds were included in the diameter. Also the mean height (above the forest floor level) of each mound was measured. All the measurements were recorded with $1 \mathrm{~cm}$ accuracy. Above-ground ant mound volumes were calculated with the half ellipsoid equation (see e.g. 
Risch et al. 2005). Mound dimensions are commonly used as surrogates for worker population size of the mounds (e.g. Seifert 1991, Deslippe \& Savolainen 1994, Liautard et al. 2003, Sorvari \& Hakkarainen 2005). We used mound dimensions also when calculating nest density estimates to be compared with those in a recent Swedish inventory: only active colonies with minimum height of $20 \mathrm{~cm}$ and minimum width of $30 \mathrm{~cm}$ were taken into account in the Swedish inventory (G. Kempe pers. comm.).

For the present preliminary analyses, we selected four stand characteristics classified in rough categories which, however, reflect the most important ecological gradients in Finnish forests: forest vegetation zones (see Ahti et al. 1968, the four sampling areas approximated roughly the boreal zones along south-north gradient), soil type (mineral soils $v s$. mires), fertility (poor $v s$. fertile, i.e. Vaccinium site type and poorer stands vs. Myrtillus site type and richer stands - for the site types, see Cajander 1949), and successional stage of the stand (open vs. closed canopy; tree-canopy cover less than or equal to $40 \%$ vs. more than $40 \%$ ). For ants, one of the most important habitat characteristics changing during forest succession is exposition to sun. Because sun exposition varies a lot with several stand characteristics (e.g. tree species composition and site type of the stand) in addition to successional stage or age of the stand, we selected tree canopy cover to approximate successional stage in our analyses. Additionally, we compared whether the occurrences of ant species differed between drained and undrained mires. We utilized the NFI classes based on the effects of ditching ("drainage succession"): drained mires are classified into recently drained mires, transforming mires and transformed mires. During drainage succession water level decreases and the growth of the tree stand accelerates.

For each active ant mound, a sample of about 20 worker ants was taken and stored in ethanol, and the samples were identified to species in the laboratory. Owing to commonly found difficulties in the identification of mound-building Formica, we consulted several identification keys and research papers (especially those dealing with chaetotaxonomy of the wood ant species) during the identification process (e.g. Dłussky
\& Pisarski 1971, Collingwood 1979, Douwes 1979, 1981a, 1981b, 1995, Vepsäläinen \& Pisarski 1981, Seifert 1991, 1996a, 1996b, 2000, 2003, Czechowski \& Douwes 1996, Czechowski et al. 2002, Goropashnaya et al. 2004a, 2004b, Sorvari 2006).

We used log-likelihood ratio test $\left(G^{2}\right)$ to evaluate whether the occurrence of species depended differently on environmental variables and also to evaluate whether the relationship was the same between abandoned and active ant mounds. When statistically significant relationships were found, we explored the cell contributions (observedexpected) to the test statistics to aid the interpretation of the test results. These analyses were performed with Statistix software, ver. 8 (Analytical Software, Tallahassee, Florida, USA).

\section{Results}

The first year's survey yielded a total of 533 active ant mounds (includes five mounds with missing location data because of incomplete sample labeling), and 178 abandoned mounds. Thus, $25 \%$ of all mounds were abandoned. Most of the sample plots (86.3\%) housed no ant mounds, and only $2.4 \%$ of the plots had more than one mound. The samples represented 14 ant species of all the four subgenera of Formica found in Finland (Table 1). Eleven of these species were truly mound-building ones: five species of wood ants of Formica rufa group ( $F$. rufa, F. polyctena, F. aquilonia, $F$. lugubris and $F$. pratensis), five species of Coptoformica (F. exsecta, $F$. fennica, $F$. pressilabris, $F$. forsslundi and $F$. suecica), and Formica uralensis. Additionally, some atypically large nests of other Formica species were found in the survey (Formica truncorum, $F$. sanguinea, and F. picea - especially the latter one, however, was evidently accidental in the samples and it was presumably housing an abandoned mound built by some other species). The distributions of the latter three species are not analyzed here because the sampling procedure heavily underestimates their occurrence. However, the present data probably reflect their overall distribution given that small and large colonies are distributed approximately similarly. The most common species were $F$. aquilonia 
(57\% of all samples), $F$. exsecta (14\%) and $F$. lugubris $(11 \%)$, and $F$. rufa, F. uralensis and $F$. polyctena comprised $2 \%-3 \%$ each (Table 1 ).

The biggest mounds were found in the wood ant group, where the largest average sizes were recorded in the polygynous species $F$. polyctena and $F$. aquilonia, 1.0 and $0.5 \mathrm{~m}^{3}$, respectively, whereas the average size was smaller in the monogynous wood ant species ( $F$. lugubris, $F$. rufa and F. pratensis, $0.1-0.4 \mathrm{~m}^{3}$, Table 1$)$. Similarly, the mounds of $F$. exsecta and $F$. fennica were five times larger than those of the rest of the Coptoformica species (Table 1). The biggest mound in these data was $6.6 \mathrm{~m}^{3}$ and it was inhabited by F. aquilonia.

The overall density of ant mounds (all species and active and abandoned mounds pooled) was on average $4.2( \pm 0.44 \mathrm{SE})$ mounds $\mathrm{ha}^{-1}$. Because the reduction in sample plot size may lead to boosted mound densities due to edge effects (see Discussion below), we examined how the size of the ant mound recording plot (the $10 \%$ size classes of the centre stand's proportion of the full $\sim 0.05$ ha sampling plot) affected the density estimate. In the smallest size classes $(10 \%-40 \%)$, the number of plots was extremely low (1-20 plots) and thus, these plots yielded hardly any ant mound observations. With $50 \%$ plot size, however, the number of plots was already reasonable and ant mounds were encountered more often. This resulted in very high density estimate and large variation, i.e. $9.1( \pm 1.93$ SE, based on 116 plots) mounds per ha (Fig. 2). The density estimate and its variation became lower with increasing plot size and increasing number of plots per size class (Fig. 2). With full $100 \%$ ( $~ 0.05 \mathrm{ha})$ sample plots, the average was 3.3 ( \pm 0.19 SE) mounds per ha (Fig. 2).

Table 1. Ant mound observations and mound characteristics (height, width, volume and density; for density, all the sample plots were used - see text) in the 4150 sample plots of NFI10 (2005), and the share of each species.

\begin{tabular}{|c|c|c|c|c|c|c|c|c|c|c|c|}
\hline \multirow[t]{3}{*}{ Species } & \multirow[t]{3}{*}{ Subgenus $^{1}$} & \multicolumn{8}{|c|}{ Mound characteristics } & \multirow[t]{3}{*}{ Tot. } & \multirow[t]{3}{*}{$\%$} \\
\hline & & \multicolumn{2}{|c|}{$\begin{array}{l}\text { Height } \\
\text { (m) }\end{array}$} & \multicolumn{2}{|c|}{$\begin{array}{l}\text { Width } \\
(\mathrm{m})\end{array}$} & \multicolumn{2}{|c|}{$\begin{array}{l}\text { Volume } \\
\qquad\left(\mathrm{m}^{3}\right)\end{array}$} & \multicolumn{2}{|c|}{$\begin{array}{c}\text { Density } \\
\left(\text { ha }^{-1}\right)\end{array}$} & & \\
\hline & & Mean & SE & Mean & SE & Mean & SE & Mean & SE & & \\
\hline Formica aquilonia & Fw & 0.53 & 0.02 & 1.00 & 0.03 & 0.52 & 0.05 & 1.60 & 0.24 & 302 & 56.7 \\
\hline Formica exsecta & $\mathrm{C}$ & 0.33 & 0.01 & 0.52 & 0.02 & 0.06 & 0.01 & 0.52 & 0.16 & 76 & 14.3 \\
\hline Formica lugubris & Fw & 0.45 & 0.03 & 0.81 & 0.06 & 0.25 & 0.04 & 0.41 & 0.12 & 58 & 10.9 \\
\hline Formica rufa & Fw & 0.49 & 0.06 & 1.02 & 0.13 & 0.40 & 0.11 & 0.06 & 0.02 & 15 & 2.8 \\
\hline Formica uralensis & $\mathrm{F}$ & 0.25 & 0.04 & 0.49 & 0.08 & 0.06 & 0.03 & 0.10 & 0.05 & 15 & 2.8 \\
\hline Formica sanguinea & $\mathrm{R}$ & 0.22 & 0.03 & 0.55 & 0.03 & 0.04 & 0.01 & 0.09 & 0.06 & 14 & 2.6 \\
\hline Formica truncorum & $\mathrm{F}$ & 0.31 & 0.04 & 0.70 & 0.08 & 0.11 & 0.04 & 0.12 & 0.06 & 13 & 2.4 \\
\hline Formica polyctena & Fw & 0.73 & 0.11 & 1.33 & 0.16 & 1.01 & 0.46 & 0.09 & 0.05 & 12 & 2.3 \\
\hline Formica fennica & $\mathrm{C}$ & 0.36 & 0.07 & 0.50 & 0.04 & 0.06 & 0.02 & 0.10 & 0.06 & 8 & 1.5 \\
\hline Formica pressilabris & $\mathrm{C}$ & 0.21 & 0.02 & 0.35 & 0.04 & 0.01 & 0.00 & 0.03 & 0.01 & 6 & 1.1 \\
\hline Formica forsslundi & C & 0.17 & 0.04 & 0.29 & 0.05 & 0.01 & 0.00 & 0.02 & 0.02 & 4 & 0.8 \\
\hline Formica pratensis & Fw & 0.17 & 0.09 & 0.60 & 0.45 & 0.07 & 0.07 & 0.01 & 0.00 & 2 & 0.4 \\
\hline Formica suecica & C & 0.17 & 0.02 & 0.36 & 0.01 & 0.01 & 0.00 & 0.01 & 0.01 & 2 & 0.4 \\
\hline Formica picea & S & 0.15 & - & 0.38 & - & 0.01 & - & - & - & 1 & 0.2 \\
\hline Missing data ${ }^{2}$ & & - & - & - & - & - & - & - & - & 5 & 0.9 \\
\hline \multicolumn{2}{|l|}{ Active mounds, all spp. } & 0.47 & 0.01 & 0.86 & 0.02 & 0.38 & 0.03 & 3.19 & 0.35 & 533 & 100.0 \\
\hline \multicolumn{2}{|l|}{ Abandoned mounds } & 0.40 & 0.02 & 0.91 & 0.04 & 0.35 & 0.04 & 1.06 & 0.20 & 178 & \\
\hline \multicolumn{2}{|c|}{ All mounds (abandoned and active) } & 0.45 & 0.01 & 0.87 & 0.02 & 0.37 & 0.03 & 4.25 & 0.44 & 711 & \\
\hline
\end{tabular}

${ }^{1}$ Abbreviations for subgenera: $\mathrm{F}=$ Formica $\mathrm{s}$. str., $\mathrm{C}=$ Coptoformica, $\mathrm{R}=$ Raptiformica, and $\mathrm{S}=$ Serviformica; $\mathrm{w}=$ the species belongs to the wood ant group ( $F$. rufa group).

${ }^{2}$ Missing data includes five ant samples identified to species ( $F$. aquilonia, $F$. exsecta, F. lugubris, $F$. sanguinea and $F$. forsslundi, one sample of each species) for which no mound or plot data was available because of incomplete sample labeling. These data were omitted from all the species specific analyses. 


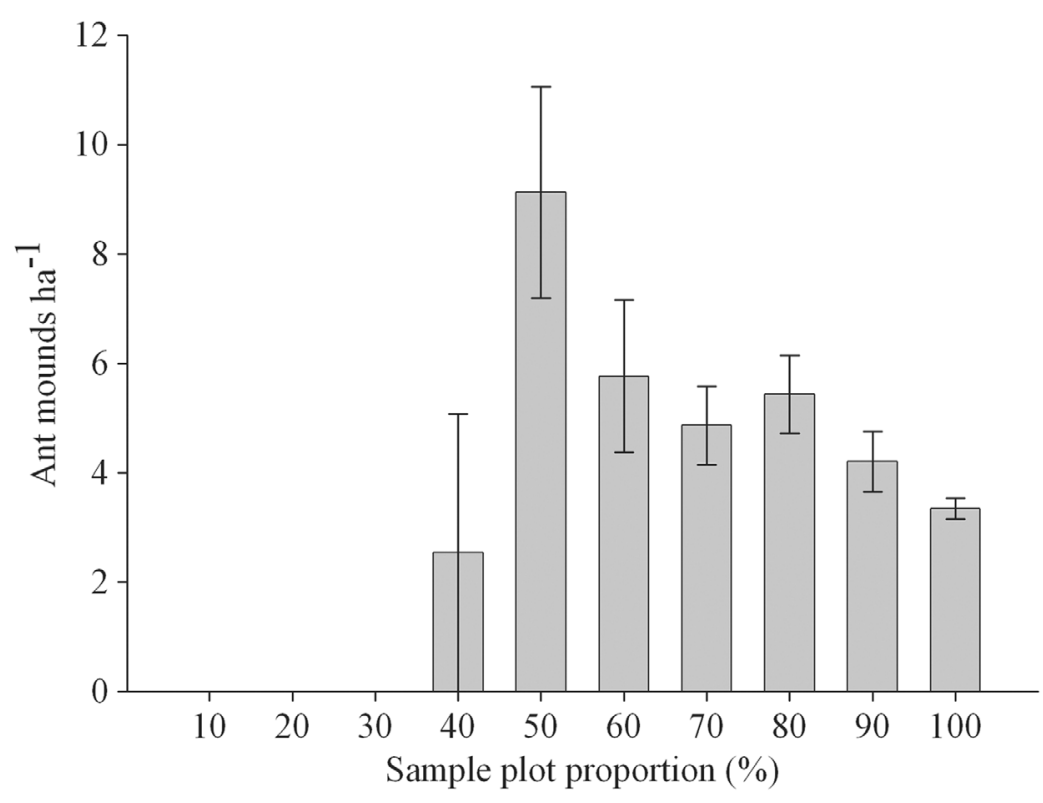

Fig. 2. Ant mound density in relation to the proportion of sample plot to the full sample plot.

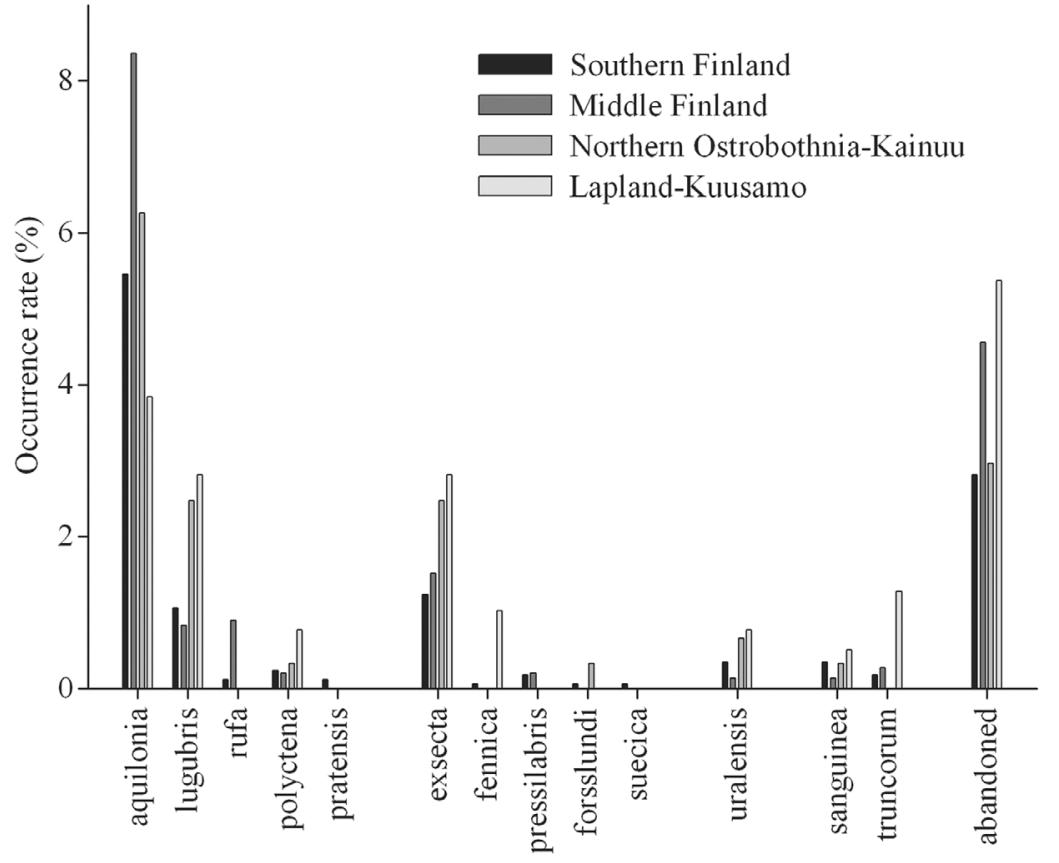

Fig. 3. The occurrence rate (\% of sample plots) of mounds of different ant species and abandoned mounds in different sampling areas.
Overall, five mound-building species ( $F$. polyctena, $F$. aquilonia, $F$. lugubris, $F$. exsecta and $F$. uralensis) occurred throughout the country, and four species (F. rufa, F. pratensis, $F$. pressilabris, and $F$. suecica) were restricted to southern parts of the country (Fig. 3). The distribution of species occurrences in relation to geographic area was clear (pooled sampling areas southern vs. northern Finland; $G^{2}=61.03, \mathrm{df}=$ 10, $p$ <.001): F. aquilonia and $F$. rufa were less and $F$. exsecta, $F$. fennica and $F$. lugubris were more frequent in the north than expected.

Although the three most common species were the same on mineral soils and mires, all the species except $F$. lugubris showed quite clear association with either of the habitat types (min- 
Fig. 4. The occurrence rate (\% of sample plots) of mounds of different ant species and abandoned mounds on different soil types.

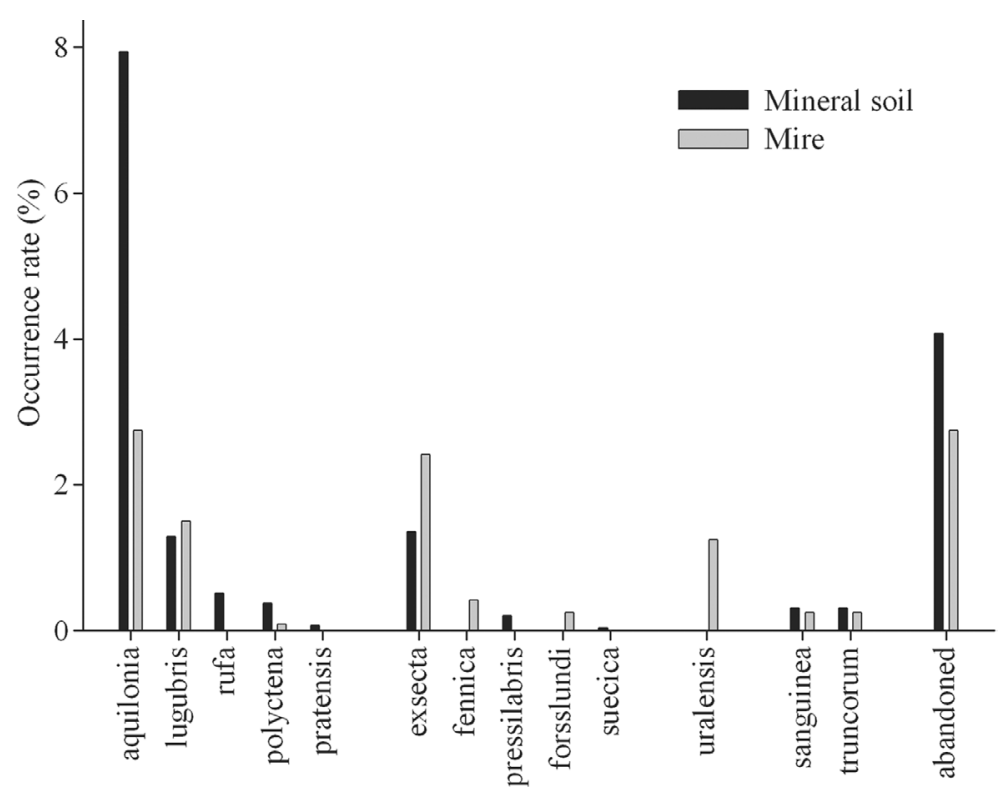

eral soils: F. rufa, F. polyctena, F. aquilonia, $F$. pratensis, $F$. pressilabris, $F$. suecica; mires: $F$. exsecta, F. fennica, F. forsslundi and F. uralensis; Fig. 4). The distribution of ant species occurrences differed clearly in relation to the habitat type (mineral soils vs. mires): F. aquilonia was less and $F$. uralensis, $F$. exsecta, $F$. fennica and $F$. forsslundi were more frequent on mires than expected $\left(G^{2}=143.12, \mathrm{df}=10, p<0.001\right)$. The overall density of ant mounds on mineral soils and mires was on average $4.4( \pm 0.23 \mathrm{SE})$ and $3.1( \pm 0.31)$ mounds per ha, respectively. With full $100 \%$ sample plots, the respective densities were $3.5( \pm 0.22)$ and $3.0( \pm 0.37)$ mounds per ha. The density estimates comparable with those of the recent Swedish inventory (see Material and methods) were $2.6( \pm 0.16)$ and $1.8( \pm 0.21)$ mounds $\mathrm{ha}^{-1}$ on mineral soils and mires, respectively.

The three species confined exclusively to mires, $F$. uralensis, $F$. fennica and $F$. forsslundi, occurred less frequently on drained mires than on undrained ones and further, their occurrence rate decreased with drainage succession, and the occurrence of abandoned mounds peaked in recently drained and transforming mires (Fig. 5). All the three species were absent from mineral soils. The only frequent species on mires that, however, was associated with mineral soils, $F$. aquilonia, seemed to have been benefited from draining (Fig. 5). The distribution of ant species occurrences differed clearly in relation to drainage classes (undrained $v s$. recently drained and transforming vs. transformed: $G^{2}=31.80, \mathrm{df}=$ $12, p=0.002): F$. aquilonia was more common on transformed mires, and $F$. fennica and $F$. uralensis were more frequent in undrained mires than expected.

Only $F$. aquilonia occurred more often under closed tree canopy than in open conditions. With two exceptions, $F$. rufa and $F$. polyctena which occurred at similar frequencies under open and closed canopy, all the rest of the species were associated with open tree canopy (Fig. 6). The distribution of ant species occurrences differed clearly in relation to canopy openness (treecanopy cover less than or equal to $40 \% \mathrm{vs}$. more than 40\%: $G^{2}=63.61$, df $\left.=10, p<0.001\right): F$. aquilonia was less and F. exsecta, F. fennica and $F$. uralensis were more frequent in open canopy stands than expected.

The polygynous wood ants, $F$. aquilonia and $F$. polyctena occurred more frequently on fertile than poor mineral soils and mires, whereas the opposite was true for most of the other species (Figs. 7 and 8). The distribution of species occurrences in relation to site fertility (fertile $v s$. poor soils) did not differ on mires $\left(G^{2}=11.26, \mathrm{df}=6\right.$, $p=0.081 ; F$. aquilonia was slightly more and $F$. forsslundi slightly less frequent on fertile mires 

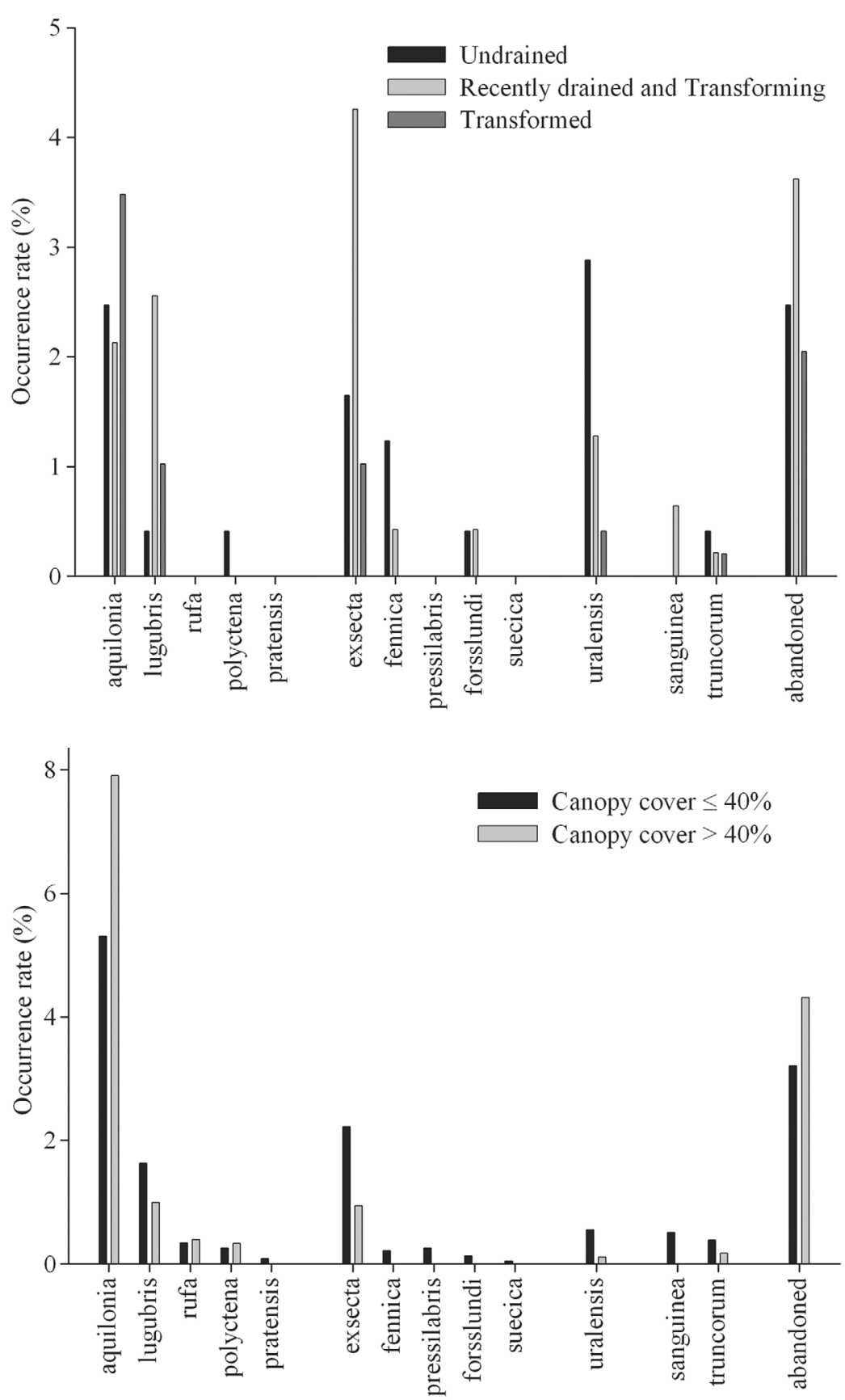

Fig. 5. The occurrence rate (\% of sample plots) of mounds of different ant species and abandoned mounds on mires in relation to drainage classes.
Fig. 6. The occurrence rate (\% of sample plots) of mounds of different ant species and abandoned mounds in relation to the tree-canopy cover. than expected but not statistically significantly so). On mineral soils, however, the distribution of species in relation to fertility differed clearly (fertile vs. poor soils: $G^{2}=45.91$, $\mathrm{df}=7, p<$ 0.001): F. aquilonia was less and F. lugubris, $F$. rufa and $F$. suecica were more frequent on poor sites than expected.
The distribution of active vs. abandoned mounds was the same in relation to geographic area (the two southernmost sampling areas vs. the two northernmost areas pooled: $G^{2}=0.64$, df $=1, p=0.424)$. Similarly, the distribution of active vs. abandoned mounds was the same also in relation to habitat type (mineral soils 
Fig. 7. The occurrence rate $(\%$ of sample plots) of mounds of different ant species and abandoned mounds in relation to the site fertility on mineral soils.

Fig. 8. The occurrence rate (\% of sample plots) of mounds of different ant species and abandoned mounds in relation to the site fertility on mires.
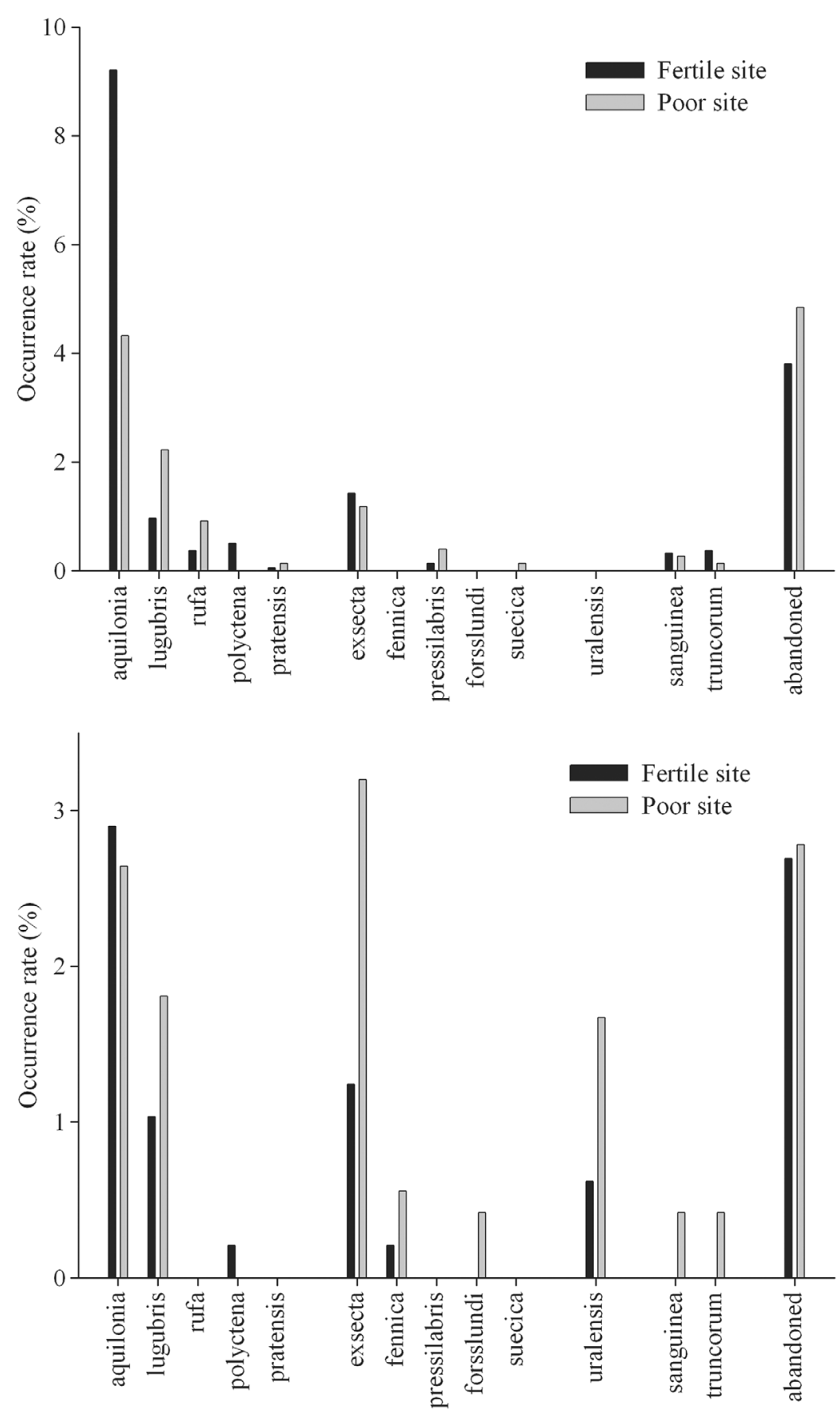

vs. mires: $\left.G^{2}=0.37, \mathrm{df}=1, p=0.541\right)$, to mire drainage classes (undrained vs. recently drained and transforming $v s$. transformed: $G^{2}=0.19$, df $=2, p=0.908)$, and to canopy cover $(\leq 40 \% v s$. $>40 \%: G^{2}=2.86, \mathrm{df}=1, p=0.091$; abandoned mounds were slightly more frequent in closed canopy forests than expected but not statistically significantly so). The distribution of active $v s$. abandoned mounds was the same in fertile and poor mires (fertile $v s$. poor soil: $G^{2}=1.77$, df $=1, p=0.184)$, but on mineral soils abandoned mounds were more frequent on poor sites than expected $\left(G^{2}=7.37\right.$, df $\left.=1, p=0.007\right)$. 


\section{Discussion}

Inclusion of species identification and information about e.g. colony vitality in the 10th Finnish National Forest Inventory made it possible to analyze mound data in much more detail than in the previous third inventory, and the analyzes revealed several new patterns of species distribution in Finland. Generally, our results verified most of the main patterns found in NFI3 (1951-1953) ant mound data (Wuorenrinne 1974, Rosengren et al. 1979, Kilpeläinen et al. 2005) where no information was available for ant species, mound size nor colony vitality: mound occurrence decreased towards the north (Fig. 3) and was higher on fertile than on poor sites (Fig. 7). Mound occurrence, however, did not depend on canopy openness in NFI10 data (Fig. 6) - canopy openness approximates early and more advanced development classes among which there were differences in the NFI3 data.

\section{Mound density, vitality and size}

On mineral soils, the overall density of ant mounds (all species and active and abandoned mounds pooled) may have increased from that at the time of NFI3 (2.5 mounds per ha, see Kilpeläinen et al. 2005) to 3.5 or 4.4 mounds per ha (based on full or all sample plots, respectively), and it seemed to be quite similar to that found in a recent national survey in Sweden: for large active mounds, the density was 2.6 and 2.2 mounds $\mathrm{ha}^{-1}$ in our data and Sweden, respectively (G. Kempe pers. comm. for the Swedish data).

It is likely that ant mound density has increased from the 1950s because of the drastic management induced changes in landscape and stand structure since that time (Punttila et al. 2005): most importantly, forest fragmentation has diminished the average stand size remarkably and thus increased the proportion of edge habitats (e.g. Wuorenrinne 1983, 1989, Löfman $\&$ Kouki 2001, 2003). The effect of edge habitats was very clear in the present data. In the sample plots where the ant sample plot size was reduced, always more than one forest stand was included in the full plot area and thus, these plots were located in various kinds of stand edges. When the size of the ant-sampling plot was reduced to $50 \%$ from the full $\sim 0.05$ ha size, the density estimate of mounds increased almost three-fold (Fig. 2). Edge effect explains the high mound density as most forest dwelling mound building ant species favour edge habitats in colony founding (Punttila 1996, Sorvari \& Hakkarainen 2005, Kilpeläinen et al. 2008).

The written instructions for the NFI3 did not contain any minimum size for ant mounds to be counted nor any information whether only active or both active and abandoned mounds were counted and thus, direct comparisons between these two inventories (NFI3 and 10) cannot be reliably done. In the present data, for instance, the density estimate increased from 2.6 to 4.4 mounds $\mathrm{ha}^{-1}$ on mineral soils when also small $(h$ $>10 \mathrm{~cm}$ ) and abandoned mounds were included in addition to active and larger $(h \geq 20 \mathrm{~cm})$ mounds. This is because small mounds with higher mortality may be very common in certain habitats and successional stages.

Abandoned mounds comprised about 10\%$16 \%$ of all mounds in previous studies on fertile (mesic Myrtillus type) and medium rich (Vaccinium-Myrtillus type) stands of different age on mineral soils (considering only true mound building species, Punttila 1996, Domisch et al. 2005, Kilpeläinen et al. 2008), but our data showed a higher proportion $(25 \%)$ of abandoned mounds probably because also less favourable site types were included.

Our results on mound sizes verified the information available on relative mound size differences among different species (cf. Collingwood 1979). We found that mounds of the polygynous species were remarkably larger than those of the monogynous ones especially in the wood ant group (Table 1). Although in our data the biggest individual mound, $6.6 \mathrm{~m}^{3}$, was inhabited by $F$. aquilonia, the average size was clearly highest in F. polyctena. All the giant mounds $>10 \mathrm{~m}^{3}$ studied in Finland have been reported to be inhabited by F. polyctena (see Wuorenrinne 1994).

\section{Species distributions}

The commonness of F. aquilonia, F. exsecta and 
F. lugubris was verified in our data (Fig. 3): these species and $F$. uralensis are widespread also according to published broad-scale maps (see Baroni Urbani \& Collingwood 1977, Collingwood 1979, Czechowski et al. 2002). The other similarly widespread species in our data, F. sanguinea and $F$. truncorum, however, do not commonly build mound-like large nests and thus, their commonness is severely underestimated in the present data. Similarly, F. suecica builds very small nests and thus, it is underrepresented in our data. Small nest size may explain also the apparent rarity of $F$. pressilabris and $F$. forsslundi in our data. Given the scarcity of occurrences of $F$. suecica and $F$. forsslundi in the distribution maps (Collingwood 1979, Czechowski et al. 2002), the few records of the species in the present data still indicate that these species may be much more common than earlier thought. The recently described Coptoformica species F. fennica (Seifert 2000) was found to be rather common in Finland: it was the second most common Coptoformica species in our data, and it was much more common in the north than in the south. Earlier it was known from a few locations in southern Finland. The scarcity of F. rufa, F. pratensis and $F$. pressilabris may partly owe to their southern distribution but unlike sometimes thought (e.g. Baroni Urbani \& Collingwood 1977, Collingwood 1979, but see Czechowski et al. 2002), $F$. polyctena was not restricted to the southern part of the country. Instead, it seemed to be more common in the north than in the south, while we found an opposite pattern in the other polygynous wood ant species, $F$. aquilonia. Different wood ant species have monopolized the polygynous "niche" in different parts of Europe (Rosengren et al. 1993), and also in the present case the lower frequency of the most potential competitor, $F$. aquilonia and most of the other species may have enhanced the spread of polygynous $F$. polyctena in the north. Similarly, F. lugubris, $F$. exsecta and $F$. uralensis may have gained habitat in the north because of the low frequency of $F$. aquilonia there. Especially F. uralensis has been suggested to be a weak competitor which may be suppressed by the stronger species (Rosengren 1969, Collingwood 1979).

\section{Habitat associations}

Previously mainly qualitative information has been available on the distribution of species between the main habitat types, mineral soils and mires (Collingwood 1976, 1979, 1999, Vepsäläinen et al. 2000). Our data showed that although the three most common species were the same in these habitat types, most of the species showed a clear association with either of the main habitats, and three species were confined to mires (Fig. 4). Perhaps the most interesting finding was that $F$. fennica occurred exclusively on mires: this species has been reported to inhabit grasslands (Seifert 2000). Treeless grasslands, however, were not included in our ant sampling. Large proportion of mires has been drained in Finland to enhance forest growth: the proportion of drained mires is about $40 \%$ in the two northernmost provinces (Oulu and Lapland, i.e. the two northernmost sampling areas and northernmost Lapland in Fig. 1, the area above ca. the latitude $\left.64^{\circ} \mathrm{N}\right)$ and about $80 \%$ in the southern provinces (Auvinen et al. 2005). The drainage started on a large scale in the 1950s when still about $80 \%$ of the mires in the southern Finland were undrained (Auvinen et al. 2005). We showed that drainage causes rapid disappearance of mound building mire ant species (see also Collingwood 1999, Vepsäläinen et al. 2000) which suggests that their populations have declined remarkably especially in the southern Finland since the 1950s (Fig. 5). In our data, three species, $F$. uralensis, $F$. fennica and $F$. forsslundi, showed a clear negative trend in their occurrence rate with time since ditching, while the opposite was found in F. aquilonia that was associated with mineral soils. The greater abundance of undrained mire habitats in the north may partly explain why $F$. exsecta, F. fennica, F. forsslundi and $F$. uralensis were more frequent there than in the south.

Punttila (1996) hypothesized that monogynous wood ant species should be more common in young successional stages before the tree canopy closure whereas polygynous wood ant species should be more common in mature, closed canopy forests. In our analyses, we used the cutpoint of $40 \%$ tree canopy cover to roughly separate open (or younger) and closed (or older) forests. Although the distribution of the two 
most common wood ant species, polygynous $F$. aquilonia and monogynous $F$. lugubris, was in accordance with the hypothesis, the data on the less frequent species may be too scanty to draw any conclusions on this matter (Fig. 6). All the other territorial species (other than the species of the wood ant group) were associated with open tree canopy which has been the case in previous studies as well (for discussion on the role of these species in ant community succession, see Punttila 1996, Punttila et al. 1996).

The distribution of active and abandoned mounds differed from each other between fertile and poor mineral soils (Fig. 7) but not between fertile and poor mires (Fig. 8). Presumably this indicates higher turnover rate of ant colonies on poor mineral soils, where monogynous species (F. lugubris, F. rufa and F. pratensis of the wood ant group) were much more common and polygynous species (F. aquilonia and $F$. polyctena of the wood ant group) much less common than on fertile soils. Life span is shorter in monogynous colonies whereas polygynous colonies may theoretically be everlasting because of continuous recruitment of new queens and support from the multinest network. On mires, polygynous strategy prevails also on poor types: some of the most frequent species were polygynous ones (e.g. F. exsecta and F. uralensis, Fig. 4) which may explain why the turnover rate, as indicated by the frequency of abandoned mounds in relation to active ones, did not differ between poor and fertile mires similarly as between poor and fertile mineral soils.

\section{Disturbance frequency vs. habitat type}

Punttila (1996) hypothesized that the monogynous strategy should be favoured on pine dominated forests on poorer soils which at that time were presumed naturally to be subject to more frequent disturbances by wildfire than spruce forests on more fertile soils. Indeed, for the last 500 years, the fire frequency has been shown to have been higher in pine dominated forests than in spruce dominated ones (Zackrisson 1977, Engelmark 1987, Wallenius et al. 2004). Since then, however, it has been shown that the firereturn interval before increased human impact also in pine dominated forests in addition to spruce dominated ones has been much longer than generally believed at the time when only short dendrochronologies ( $<500 \mathrm{yrs})$ were available although the frequency may have differed among the site types (see Pitkänen et al. 2002, 2003a, 2003b, Wallenius 2002, Wallenius et al. 2004, 2005). We evaluate the hypothesis of Punttila (1996) under the light of these new findings below.

Under natural conditions fire frequencies in general were low and thus, the monogynous strategy might be viewed as an pre-adaptation to human induced elevated fire frequency rather than as an adaptation to naturally high disturbance frequency as such. As forest fires on all forest site types have been efficiently prevented for decades and natural disturbances (storms, fires, floods, insect outbreaks, etc.) leading to forest regeneration have been replaced with thinning and regeneration cuttings (clearcutting), and rotation cycles of managed forests on poor soils are generally longer than on fertile soils (e.g. according to the present forest management guidelines 70-90 years on fertile and 80-120 years on poor soils in Southern Finland, see Metsätalouden kehittämiskeskus Tapio 2006: p. 34 ), we should not expect us to find disturbance related distribution patterns in the sense of the hypothesis of Punttila (1996). Our data showed that the monogynous wood ant species were more frequent and polygynous ones less frequent on poor mineral soils than on fertile soils (Fig. 7) just as predicted by the hypothesis (Punttila 1996). The most likely explanation for this may, however, not be the higher disturbance frequency on these soils but rather the low fertility and open tree-canopy cover of these forests as such. Open tree canopy cover is favourable for colony founding in mound building ants in general. Low fertility, on the other hand, may also indicate low amounts of resources for wood ants and thus, we expect smaller colony population size in ant mounds on poor soils. Both low site fertility and monogynous strategy associate with small colony population size. A small colony population remain dependent on direct sunlight during the whole colony cycle to be able to reach and maintain sufficient intracolony temperature. This is because mere metabolic 
heat production by small worker force does not allow thermoregulation independent from sun exposition unlike in the abundantly populated mounds of the polygynous wood ant species (see Rosengren et al. 1987). The preconditions for the success of the monogynous strategy in wood ants are met on poor soils where the tree canopy of pine dominated forests remain relatively open throughout most of the successional cycle. The above disturbance and habitat hypotheses, however, do not exclude but complement each other.

\section{Acknowledgements}

Thanks to Kari T. Korhonen and others responsible for the NFI10 for accepting the ant assay as part of the survey, and for NFI field staff for data collection, and Antti Ihalainen for discussing the details of NFI sampling. Leena Finér, Pekka Niemelä, Martin Jurgensen, Liselotte Sundström, Hannu Mannerkoski and Timo Domisch initially thought up to compare NFI3 data on ants with fresh data. We thank Jouni Sorvari for helping in the identification of the ants by verifying several tricky samples. Ilpo K. Hanski, Heikki Kotiranta, Juha Pöyry, Anita C. Risch, Kari Vepsäläinen and two anonymous referees gave valuable comments on the manuscript. Academy of Finland financed the study (projects 200870 and 640026).

\section{References}

Aho, T., Kuitunen, M., Suhonen, J., Jäntti, A. \& Hakkari, T. 1999: Reproductive success of Eurasian treecreepers, Certhia familiaris, lower in territories with wood ants. - Ecology 80: 998-1007.

Ahti, T., Hämet-Ahti, L. \& Jalas, J. 1968: Vegetation zones and their sections in northwestern Europe. - Annales Botanici Fennici 5: 169-211.

Atlegrim, O. 2005: Indirect effects of ant predation (Hymenoptera : Formicidae) on bilberry Vaccinium myrtillus. - European Journal of Entomology 102: 175-180.

Auvinen, A.-P., Aapala, K., Kaipiainen, H. \& Toivonen, H. 2005: Suot. - In: Hildén, M., Auvinen, A.-P. \& Primmer, E. (eds.), Suomen biodiversiteettiohjelman arviointi [Evaluation of the Finnish national action plan for biodiversity]: 51-56. Suomen ympäristö 770. Suomen ympäristökeskus, Helsinki. [In Finnish with English summary].

Baroni Urbani, C. \& Collingwood, C. A. 1977: The zoogeography of ants (Hymenoptera, Formicidae) in northern Europe. - Acta Zoologica Fennica 152: 1-34.

Buckley, R. C. 1982a: Ant-plant interactions: a world review. - In: Buckley, R. C. (ed.), Ant-plant interactions in Australia: 111-141. Dr. W. Junk Publishers, The Hague.

Buckley, R. C. 1982b: A world bibliography of ant-plant interactions. - In: Buckley, R. C. (ed.), Ant-plant interactions in Australia: 143-162. Dr. W. Junk Publishers, The Hague.

Burzyński, J. 1969: Mrówka rudnica i mrówka ćmawa (Formica rufa L. i Formica polyctena Först.), ich liczebność i rozmieszczenie w lasach Polski [Formica rufa L. and Formica polyctena Först., their abundance and distribution in forests in Poland]. - Sylwan, Warszawa 5: 65-70. [In Polish with English summary].

Cajander, A. K. 1949: Forest site types and their signifigance. - Acta Forestalia Fennica 56: 1-71.

Collingwood, C.A. 1976: Mire invertebrate fauna at Eidskog, Norway. III. Formicidae (Hymenoptera Aculeata). Norwegian Journal of Entomology 23: 185-187.

Collingwood, C. A. 1979: The Formicidae (Hymenoptera) of Fennoscandia and Denmark. - Fauna Entomologica Scandinavica 8: 1-174.

Collingwood, C. A. 1999: Changes in the ant (Hym.: Formicidae) fauna of a Swedish bogland area 1986-1997. - Entomologist's Record and Journal of Variation 111: 233-234.

Czechowski, W. \& Douwes, P. 1996: Morphometric characteristics of Formica polyctena Foerst. and Formica rufa L. (Hymenoptera, Formicidae) from the Gorce Mts; interspecific and intraspecific variations. - Annales Zoologici, Warszawa 46: 125-141.

Czechowski, W., Radchenko, A. \& Czechowska, W. 2002: The ants (Hymenoptera, Formicidae) of Poland. Museum and Institute of Zoology PAS (Polish Academy of Sciences), Warszawa.

Deslippe, R. J. \& Savolainen, R. 1994: Role of food supply in structuring a population of Formica ants. - Journal of Animal Ecology 63: 756-764.

Dłussky, G. M. \& Pisarski, B. 1971: Rewizja polskich gatunków mrówek (Hymenoptera: Formicidae) z rodzaju Formica L. - Fragmenta Faunistica (Warszawa) 16: 145-224.

Domisch, T., Finér, L. \& Jurgensen, M. F. 2005: Red wood ant mound densities in managed boreal forests. Annales Zoologici Fennici 42: 277-282.

Douwes, P. 1979: Formica rufa-gruppens systematik. Entomologisk Tidskrift 100: 187-191.

Douwes, P. 1981a: Intraspecific and interspecific variation in workers of the Formica rufa group (Hymenoptera: Formicidae) in Sweden. - Entomologica Scandinavica Supplement 15: 213-223.

Douwes, P. 1981b: Hur man känner igen de olika arterna av den vanliga stackmyran. - Entomologisk Tidskrift 102: 80-82.

Douwes, P. 1995: Sveriges myror. - Entomologisk Tidskrift 116: 83-99.

Elgmork, K. \& Kaasa, J. 1992: Food habits and foraging of the brown bear Ursus arctos in central south Norway. - Ecography 15: 101-110.

Engelmark, O. 1987: Fire history correlations to forest type and topography in northern Sweden. - Annales Botanici Fennici 24: 317-324.

Goropashnaya, A. V., Fedorov, V. B. \& Pamilo, P. 2004a: Recent speciation in the Formica rufa group ants (Hymenoptera, Formicidae): inference from mitochon- 
drial DNA phylogeny. - Molecular Phylogenetics and Evolution 32: 198-206.

Goropashnaya, A. V., Fedorov, V. B., Seifert, B. \& Pamilo, P. 2004b: Limited phylogeographical structure across Eurasia in two red wood ant species Formica pratensis and F. lugubris (Hymenoptera, Formicidae). - Molecular Ecology 13: 1849-1858.

Gösswald, K. 1990: Die Waldameise. Band 2. Die Waldameise im Ökosystem Wald, ihr Nutzen und ihre Hege. - AULA-Verlag GmbH.

Haemig, P. D. 1992: Competition between ants and birds in a Swedish forest. - Oikos 65: 479-483.

Haemig, P. D. 1994: Effects of ants on the foraging of birds in spruce trees. - Oecologia 97: 35-40.

Hölldobler, B. \& Wilson, E. O. 1990: The ants. - Harvard University Press.

Jäntti, A., Suorsa, P., Hakkarainen, H., Sorvari, J., Huhta, E. \& Kuitunen, M. 2007: Within territory abundance of red wood ants Formica rufa is associated with the body condition of nestlings in the Eurasian treecreeper Certhia familiaris. - Journal of Avian Biology 38: 619-624.

Kalela, A. 1960: Metsäkasvillisuusvyöhykkeet, Chapter 10: Kasvisto ja kasvillisuusvyöhykkeet: map 17. - In: Aario, L. (ed.) Suomen kartasto - Atlas of Finland. Otava, Helsinki.

Karhu, K. J. \& Neuvonen, S. 1998: Wood ants and a geometrid defoliator of birch: predation outweighs beneficial effects through the host plant. - Oecologia 113: 509-516.

Kilpeläinen, J., Punttila, P., Sundström, L., Niemelä, P. \& Finér, L. 2005: Forest stand structure, site type and distribution of ant mounds in boreal forests in Finland in the 1950s. - Annales Zoologici Fennici 42: 243-258.

Kilpeläinen, J., Finér, L., Niemelä, P., Domisch, T., Neuvonen, S., Ohashi, M., Risch, A. C. \& Sundström, L. 2007: Carbon, nitrogen and phosphorus dynamics of ant mounds (Formica rufa group) in managed boreal forests of different successional stages. - Applied Soil Ecology 36: 156-163.

Kilpeläinen, J., Punttila, P., Finér, L., Niemelä, P., Domisch, T., Jurgensen, M. F., Neuvonen, S., Ohashi, M., Risch, A. C. \& Sundström, L. 2008: Distribution of ant species and mounds (Formica) in different aged managed spruce stands in eastern Finland. - Journal of Applied Entomology 132: 315-325.

Korhonen, K. T., Ihalainen, A., Heikkinen, J., Henttonen, H. \& Pitkänen, J. 2007: Suomen metsävarat metsäkeskuksittain 2004-2006 ja metsävarojen kehitys 1996-2006. - Metsätieteen aikakauskirja 2B/2007: 149-213.

Korhonen, K. T., Heikkinen, J., Henttonen, H., Ihalainen, A., Pitkänen, J. \& Tuomainen, T. 2006: Suomen metsävarat 2004-2005. - Metsätieteen aikakauskirja 1B/2006: 183-221.

Laakso, J. \& Setälä, H. 2000: Impacts of wood ants (Formica aquilonia Yarr.) on the invertebrate food web of the boreal forest floor. - Annales Zoologici Fennici 37: 93-100.

Lehtinen, P. 1987: Association of uropodid, prodinychid, polyaspidid, antennophorid, sejid, microgynid, and zerconid mites with ants. - Entomologisk Tidskrift 108: 13-20.
Lenoir, L., Persson, T. \& Bengtsson, J. 2001: Wood ant nests as potential hot spots for carbon and nitrogen mineralisation. - Biology and Fertility of Soils 34: 235-240.

Liautard, C., Brown, W. D., Helms, K. R. \& Keller, L. 2003: Temporal and spatial variations of gyne production in the ant Formica exsecta. - Oecologia 136: 558-564.

Löfman, S. \& Kouki, J. 2001: Fifty years of landscape transformation in managed forests of Southern Finland. - Scandinavian Journal of Forest Research 16: 44-53.

Löfman, S. \& Kouki, J. 2003: Scale and dynamics of a transforming forest landscape. - Forest Ecology and Management 175: 247-252.

Mahdi, T. \& Whittaker, J. B. 1993: Do birch trees (Betula pendula) grow better if foraged by wood ants. - Journal of Animal Ecology 62: 101-116.

Martikainen, P., Siitonen, J., Punttila, P., Kaila, L. \& Rauh, J. 2000: Species richness of Coleoptera in mature managed and old-growth boreal forests in southern Finland. - Biological Conservation 94: 199-209.

Metsätalouden kehittämiskeskus Tapio 2006: Hyvän metsänhoidon suositukset. - Metsätalouden kehittämiskeskus Tapion julkaisusarja 22/2006: 1-100.

Niemelä, J., Haila, Y., Halme, E., Pajunen, T. \& Punttila, P. 1992: Small-scale heterogeneity in the spatial distribution of carabid beetles in the southern Finnish taiga. - Journal of Biogeography 19: 173-181.

Pileckis, S. \& Vilkauskas, L. [Пилецкис, C. \& Вилкаускас, Л.] 1973: [The experience to estimated the ant-hills in the forests of the Lithuanian SSR by means of a mathematical-statistical method]. - Acta Entomologica Lituanica 2: 49-62. [In Russian].

Pitkänen, A., Huttunen, P., Jungner, H. \& Tolonen, K. 2002: A 10000 year local forest fire history in a dry heath forest site in eastern Finland, reconstructed from charcoal layer records of a small mire. - Canadian Journal of Forest Research 32: 1875-1880.

Pitkänen, A., Huttunen, P., Tolonen, K. \& Jungner, H. 2003a: Long-term fire frequency in the spruce-dominated forests of the Ulvinsalo strict nature reserve, Finland. - Forest Ecology and Management 176: 305-319.

Pitkänen, A., Huttunen, P., Jungner, H., Meriläinen, J. \& Tolonen, K. 2003b: Holocene fire history of middle boreal pine forest sites in eastern Finland. - Annales Botanici Fennici 40: 15-33.

Pokarzhevskij, A. D. 1981: The distribution and accumulation of nutrients in nests of ant Formica polyctena (Hymenoptera, Formicidae). - Pedobiologia 21: 117-124.

Punttila, P. 1996: Succession, forest fragmentation, and the distribution of wood ants. - Oikos 75: 291-298.

Punttila, P., Haila, Y. \& Tukia, H. 1996: Ant communities in taiga clearcuts: habitat effects and species interactions. - Ecography 19: 16-28.

Punttila, P., Niemelä, P. \& Karhu, K. 2004: The impact of wood ants (Hymenoptera : Formicidae) on the structure of invertebrate community on mountain birch (Betula pubescens ssp. czerepanovii). - Annales Zoologici Fennici 41: 429-446.

Punttila, P., Haila, Y., Niemelä, J. \& Pajunen, T. 1994: Ant communities in fragments of old-growth taiga and managed surroundings. - Annales Zoologici Fennici 31: 
131-144.

Punttila, P., Virkkala, R., Auvinen, A.-P., Toivonen, H., Kaipiainen, H., Söderman, G. \& Mannerkoski, I. 2005: Metsät [Forests]. - In: Hildén, M., Auvinen, A.-P. \& Primmer, E. (eds.), Suomen biodiversiteettiohjelman arviointi [Evaluation of the Finnish national action plan for biodiversity]: 37-51, Suomen ympäristö 770, Suomen ympäristökeskus, Helsinki. [In Finnish with English summary].

Päivinen, J., Ahlroth, P. \& Kaitala, V. 2002: Ant-associated beetles of Fennoscandia and Denmark. - Entomologica Fennica 13: 20-40.

Risch, A. C., Jurgensen, M. F., Schütz, M. \& Page-Dumroese, D. S. 2005: The contribution of red wood ants to soil $\mathrm{C}$ and $\mathrm{N}$ pools and $\mathrm{CO}_{2}$ emissions in subalpine forests. - Ecology 86: 419-430.

Rosengren, R. 1969: Notes regarding the growth of a polycalic nest system in Formica uralensis Ruzsky. - Notulae Entomologicae 49: 211-230.

Rosengren, R. \& Sundström, L. 1991: The interaction between red wood ants, Cinara aphids and pines. A ghost of mutualism past? - In: Huxley, C. R. \& Cutler, D. F. (eds.), Ant-plant interactions: 80-91 Oxford University Press, Oxford, New York, Tokyo.

Rosengren, R., Vepsäläinen, K. \& Wuorenrinne, H. 1979: Distribution, nest densities and ecological significance of wood ants (the Formica rufa group) in Finland. - West Palaearctic Regional Section Bulletin, International Organization for the Biological Control of Noxious Animals and Plants II-3: 181-213.

Rosengren, R., Sundström, L. \& Fortelius, W. 1993: Monogyny and polygyny in Formica ants: the results of alternative dispersal tactics. - In: Keller, L. (ed.), Queen number and sociality in insects: 308-333. Oxford University Press.

Rosengren, R., Fortelius, W., Lindström, K. \& Luther, A. 1987: Phenology and causation of nest heating and thermoregulation in red wood ants of the Formica rufa group studied in coniferous forest habitats in southern Finland. - Annales Zoologici Fennici 24: 147-155.

Savolainen, R. \& Vepsäläinen, K. 1988: A competition hierarchy among boreal ants - impact on resource partitioning and community structure. - Oikos 51: 135-155.

Seifert, B. 1991: The phenotypes of the Formica rufa complex in East Germany. - Abhandlungen und Berichte des Naturkundemuseums Görlitz 65: 1-27.

Seifert, B. 1996a: Formica paralugubris nov. spec. - a sympatric sibling species of Formica lugubris from the western Alps (Insecta: Hymenoptera: Formicoidea: Formicidae). - Reichenbachia 31: 193-201.

Seifert, B. 1996b: Ameisen beobachten, bestimmen. - Naturbuch Verlag.

Seifert, B. 2000: A taxonomic revision of the ant subgenus Coptoformica Mueller, 1923 (Hymenoptera: Formicidae). - Zoosystema 22: 517-568.

Seifert, B. 2003: The "Hippie Ant" - a case of extreme intranidal polymorphism in Fennoscandian Formica lugubris. - Sociobiology 42: 285-297.
Sipura, M. 2002: Contrasting effects of ants on the herbivory and growth of two willow species. - Ecology 83: 2680-2690.

Sorvari, J. 2006: Two distinct morphs in the wood ant Formica polyctena in Finland: a result of hybridization? - Entomologica Fennica 17: 1-7.

Sorvari, J. \& Hakkarainen, H. 2005: Deforestation reduces nest mound size and decreases the production of sexual offspring in the wood ant Formica aquilonia. - Annales Zoologici Fennici 42: 259-267.

Swenson, J. E., Jansson, A., Riig, R. \& Sandegren, F. 1999: Bears and ants: myrmecophagy by brown bears in central Scandinavia. - Canadian Journal of Zoology 77: $551-561$.

Wallenius, T. 2002: Forest age distribution and traces of past fires in a natural boreal landscape dominated by Picea abies. - Silva Fennica 36: 201-211.

Wallenius, T. H., Kuuluvainen, T. \& Vanha-Majamaa, I. 2004: Fire history in relation to site type and vegetation in Vienansalo wilderness in eastern Fennoscandia, Russia. - Canadian Journal of Forest Research 34: 1400-1409.

Wallenius, T. H., Pitkänen, A., Kuuluvainen, T., Pennanen, J. \& Karttunen, H. 2005: Fire history and forest age distribution of an unmanaged Picea abies dominated landscape. - Canadian Journal of Forest Research 35: 1540-1552.

Way, M. J. \& Khoo, K. C. 1992: Role of ants in pest management. - Annual Review of Entomology 37: 479-503.

Wellenstein, G. 1980: Auswirkung hugelbauender Waldameisen der Formica rufa-Gruppe auf forstschadliche Raupen und das Wachstum der Waldbaume. - Zeitschrift für Angewandte Entomologie 89: 144-157.

Vepsäläinen, K. \& Pisarski, B. 1981: The taxonomy of the Formica rufa group: chaos before order. - In: Howse, P. E. \& Clément, J. L. (eds.), Biosystematics of social insects. Systematics Association Special Volume 19: $27-$ 35. Academic Press.

Vepsäläinen, K., Savolainen, R., Tiainen, J. \& Vilén, J. 2000: Successional changes of ant assemblages: from virgin and ditched bogs to forests. - Annales Zoologici Fennici 37: 135-149.

Wuorenrinne, H. 1974: Suomen kekomuurahaisten (Formica rufa Coll.) ekologiasta ja levinneisyydesta. - Silva Fennica 8: 205-214.

Wuorenrinne, H. 1983: Der Einfluss der Waldsplitterung auf Ameisengesellschaften am Beispiel von Espoo (Finland). - Tagungsbericht 2. Leipziger Symposium urbane Ökologie 1983: 25-30.

Wuorenrinne, H. 1989: Effects of urban pressure on colonies of Formica rufa group (Hymenoptera, Formicidae) in the town of Espoo (Finland). - Annales Zoologici, Warszawa 42: 335-344.

Wuorenrinne, H. 1994: Some interesting features on Finnish wood ant mounds. - Memorabilia Zoologica 48: 261-265.

Zackrisson, O. 1977: Influence of forest fires on the North Swedish boreal forest. - Oikos 29: 22-32. 